\title{
ISLAM AND HUMAN RIGHTS WITH SPECIAL REFERENCE TO THE UNIVERSAL HUMAN RIGHTS AND THE CAIRO DECLARATION ON HUMAN RIGHTS
}

\author{
Adam Hamisi Mwamburi ${ }^{1}$ \\ AbdulGafar Olawale Fahm²
}

\begin{abstract}
This article discusses the Islam and Human Rights while making significant reference to the Universal Declaration of Human Rights 1948 and Cairo Declaration of Human Rights 1990. It argues that the Universal Declaration on Human Rights (UNDR) 1948 and the Cairo Declaration on Human Rights (CDHR) 1990 in Islam have major differences which cannot be reconciled. The UNDR, for instance, cannot be relied upon by Muslims because of its severe discrepancies and opposition to the Islamic law. The thrust of the article is that the purported universal rights meant for specific people especially the western world and not the whole humanity. Any attempts by a section of Muslim to implement these rights collectively means that they will have to abandon the teachings of Islam at the expense of the secular western values.
\end{abstract}

Keywords: Islam, Human Rights, Universal Human Rights, Cairo Declaration

Lecturer, Islamic Religious Education, RAF International University Mombasa, Kenya, adamkhamis74@gmail.com

2 Lecturer, Department of Religions, Faculty of Arts, University of Ilorin, Ilorin, Nigeria, 23431,fahm.ao@unilorin.edu.ng 


\section{INTRODUCTION}

The Universal Declaration of Human Rights (UDHR) is a turning point document in the history of human rights. It was drafted by representatives of different countries from various legal and cultural background of the world. The Declaration was publicized by the United Nations General Assembly in Paris on 10 December 1948 (General Assembly resolution 217 A) as a typical standard of accomplishments for all people and all countries. It sets out, for the first time, fundamental human rights to be universally protected and this is why it has been translated into more than 500 languages. $^{3}$

Furthermore, the Cairo Declaration on Human Rights in Islam (CDHRI) is a declaration supported by countries that made up the Organization of the Islamic Conference in Cairo, Egypt, on 5 August 1990. The Declaration was made at the Conference of Foreign Ministers of various member states of the Organization. It was made from the Islamic point of view on human rights, and it insists on Shariah as its sole source. CDHRI pronounces its motivation to be "general direction for Member States [of the OIC] in the field of human rights". ${ }^{4}$ The Declaration reaffirms the civilizing and verifiable part of the Islamic community which the Qur'an described as the best community and which gave mankind an all-inclusive and highly balanced civilization, in which congruity is emphasized in both worlds.

Admittedly, Islam is a comprehensive way of life which has covered all aspects of life, spiritually, socially, economically etc. Therefore Islam is in conformity with human rights phenomenon, thus the understanding of human rights should be made to conform to the teaching of Islam so that it can be accepted by Muslims. The source of human rights in Islam is from Allah (Quran and Sunnah) while the source of western human rights is from the people, "let the people decide". Omar Jah in his journal article published by al-Shajarah defines the human rights concept by stating that; "They are rights considered to be a product of reason and not given to man by God"s. Also Jack Donnelley in his book International Human Rights, clearly states: "The term human rights indicate both their nature and source: they are rights

$3 \quad$ United Nation General Assembly, 'Universal Declaration of Human Rights,' The International Journal of Human Rights, 2/3 (1998): 84-88.

4 Anonymous, 'Cairo Declaration on Human Rights in Islam: Adopted and Issued at the Nineteenth Islamic Conference of Foreign Ministers in Cairo on 5 August 1990,' Forced Migration Review, 8 (2012).

5 Jah Omar, 'Human Rights in Islam: Judicial Rights, Sanction and Penalties,' $A l$ Shajarah, 7/1 (2002): 89. 
one has simply because he is human". ${ }^{6}$ This statements of Donnelley and Jah clearly demonstrates that the Universal Declaration of Human Rights 1948 are worldly and material rights which religion is not considered as a determining factor or a reference in making an interpretation.

Questions over the compatibility of Islam and Human Rights have become a key area of debate in the perceived tensions between 'Islam and the West'. In many ways, discussion over the stance of Islam in relation to such factors as gender rights, religious freedom, social and political freedoms, and other related issues represents a microcosm of the broader experience of how Muslim and 'Western' communities interact and relate. This paper, therefore, seek a firsthand comprehension of the Islamic disposition and position on human rights, we examine the human rights concerns in the contemporary society and need to understand values, principles, and perception of human rights discourse, In addition, we also examine the Universal Declaration of Human Rights 1948 versus Cairo Declaration on Human Rights 1990, and Human Rights in the Muslim world.

\section{HUMAN RIGHTS CONCERNS}

As a result, and on the basis that these rights are a pure product of human reason and not from God, it cannot be free from discrepancies and shortcomings as human beings are not perfect. Accordingly, there is no consistency in upholding international human rights, instead, it is surrounded with a lot of double standards and controversies especially after the September 11 events, where gross human rights violations have been documented. A good and contemporary example is, Guantanamo Bay Centre in Cuba, where Muslims all over the world are arbitrarily arrested, extradited to other countries well known for human rights abuse, without due legal process of the law, is denial access to legal representation, indefinite detention and denial right for a fair trial, use of torture as an interrogation techniques to terrorism suspects and many other abuses practiced by the western world who claim to be the champions of human rights. Therefore human rights discourse is not universal as alleged but rather they are selectively implemented according to the interests of the group, especially western world countries. For example, the Palestinian - Israel crisis, there is gross human rights violation committed against the children, women

6 Jack Donnelley, International Human Rights, 2nd ed. (Colorado and Oxford: West View Press, 1998), 18. 
and other non-combatant citizens of Palestine. Unfortunately, this is tolerated by some western countries, to an extent of providing huge military assistance. ${ }^{7}$

In order to critically understand the whole concept of human rights, we need to understand values, principles, and perception of human rights discourse. These are instruments of human rights which Jah Omar in his journal article on Human Rights in Islam, explains and defines them as the authority of human rights lies entirely on human reason and intellect, all individuals are considered equal regardless of religion, race, colour, sex, language etc. Any opinion, statements including religious scriptures are open to critique and values become valid if they can be argued. ${ }^{8}$ After understanding these instruments one will fully comprehend the human rights discourse, values and attitudes hence becoming extremely cautious while comparing between human rights and Islam.

Muslim writings and scholars views the human rights phenomenon with different understanding and perception. These pertinent views can be explained and categorized as follows:

a) There is a section of Muslim scholars who rejects the connection between Islam and human rights, arguing that the contemporary human rights are an exclusive western world values and civilization imposed to the whole world as universal under the United Nations Charters. Additionally, this group substantiates that, if we want to acknowledge that the western human rights values are part of Islamic teachings, then there will be a dilemma of making Islam and Shariah to conform to the western values of which are totally against the teaching of the Quran. For example, homosexuality is an abominable act in Islam, and therefore totally forbidden to be practised even to advocate for it. While on the other hand, homosexuality in the western world is cherished, promoted and protected by legislation under the Bills of Rights, hence curtailing their rights amounts to discrimination and subsequently prosecution for the offenders. This trend of rejecting human rights discourse in totality without reservations is considered as an extreme opinion, bearing in mind that there are some western human rights values which conform to the teachings of Islam, for example, rights to asylum seekers and refugees etc. In this regard, Omar Kasule in his book on human rights discourse in Islam refers to it as an exclusivist trend. ${ }^{9}$

7 Jah Omar, 'Human Rights in Islam: Judicial Rights, Sanction and Penalties,' 100.

8 Jah Omar, 'Human Rights in Islam: Judicial Rights, Sanction and Penalties,' 89.

9 Kasule Omar, Contemporary Muslims and Human Rights Discourse: A Critical Assessment (Malaysia: IIUM Press, 2009), 10, 11. 
b) The second group and opinion affirms that, teaching of Islam stands for human rights, liberation of human beings from all kinds of slavery, fights oppression, corruption and all kinds of justice since time immemorial. Therefore it's the western world understanding of human rights be made to conform to the teachings of Islam and not vice versa. This perception is referred by Omar Kasule in his book Contemporary Muslims and Human Rights Discourse: A Critical Assessment as conformist trend. ${ }^{10}$ In this context, Abu A'ala Maududi, affirms the concept of human rights but confine it to the rights conferred by Allah to his creatures and not those granted by human being. He clarifies this stance in his book, Human Rights in Islam, which he states:

"When we speak of human rights in Islam we mean those rights granted by God. Rights granted by kings or legislative assemblies can be withdrawn as easily as they are conferred, but no individual and no constitution has the authority to withdraw the rights conferred by God..." 11

c) The last trend is unpopular, which basically rejects the human rights issue outrightly, and they fiercely oppose to any group which tries to link between Islam and western human rights values. They view human rights as pure western world tool of Christian missionary aimed at deviating Muslims from following the straight path of Islam. This trend is considered as dismissive trend. ${ }^{12}$

d) Those who accept UNHR 1948 as long as its provisions are not against the teaching of Islam. ${ }^{13}$

10 Kasule Omar, Contemporary Muslims and Human Rights Discourse: A Critical Assessment, 10, 11.

11 Abu A'ala Maududi, Human Rights in Islam (London, Nairobi, Kano: Islamic Foundation, 1983), 15.

12 Kasule Omar, Contemporary Muslims and Human Rights Discourse: A Critical Assessment, 10, 11.

13 See Mashood Baderin, 'Islam and the Realization of Human Rights in the Muslim World: A Reflection on Two Essential Approaches and Two Divergent Perspectives,' Muslim World Journal of Human Rights, 4/1 (2007): 3. 


\section{COMPARING BETWEEN UNIVERSAL DECLARATION OF HUMAN RIGHTS 1948 VERSUS CAIRO DECLARATION ON HUMAN RIGHTS 1990}

After critically reading the two declarations separately and then we compared and contrasted the differences, we therefore assume that, the Cairo Declaration on Human rights came as a reaction to the long existing the Universal Declaration in 1948, ${ }^{14}$ before the Cairo Declaration formed in $1990 .{ }^{15}$ Shortcomings in the Universal Declaration of Human Rights are apparent, they did not consider religion as a factor while preparing the Declaration, therefore undermining values cherished by religious people especially Muslims. As a result, the Cairo Declaration on Human Rights which was prepared under the auspices of the Organization of Islamic Conference (OIC), aimed at demonstrating the dire need for the world to consider Islam as a viable proposition to the world materialistic civilisation crisis. The Cairo Declaration asserts that, fundamental rights in Islam are part and parcel of Islam, and human beings have no right to violate these rights as they are binding divine commandments of Allah ${ }^{16}$. The major difference that emanates from the two Declarations are the sources, the Cairo Declaration clearly affirms its source as Shariah as stated in Article 25:

"The Islamic Sharia is the only source of reference for the explanation or clarification of any of the articles of this Declaration..."

While the Universal Declaration, United Nation is the author and has the sole mandate to interpret the Declaration. Articles 29 (3) and 30 respectively of the Universal Declaration of Human Rights state:

"These rights and freedoms may in no case be exercised contrary to the purposes and principles of the United Nations"

"Nothing in this Declaration may be interpreted as implying for any state, group or person any right to engage in any activity or to perform any act aimed at the destruction of any of the rights and freedoms set forth herein".

\footnotetext{
14 Lawson Edward (ed.), Encyclopedia of Human Rights (New York, Philadelphia, Washington and London: Taylor and Francis Inc., 1991), 1655-1657.

15 Kasule Omar, Contemporary Muslims and Human Rights Discourse: A Critical Assessment, 260.

16 Kasule Omar, Contemporary Muslims and Human Rights Discourse: A Critical Assessment, 253.
} 
The following are my observations in analyzing the two Declarations:

The Universal Declaration of Human Rights 1948 has repeatedly used the word dignity or human dignity as the basis and foundation of freedom, justice, and peace in the world. Article 1 states:

"All human being is born free and equal in dignity and rights. They are endowed with reason and conscience and should act towards one another in a spirit of brotherhood."

Likewise, the Cairo Declaration of Human Rights 1990 confirms and affirms dignity by confining it to basic dignity. Article 1(A) states:

"All human beings form one family whose members are united by submission to God and descent from Adam. All men are equal in terms of basic human dignity and basic obligations and responsibilities, without any discrimination on the grounds of race, colour, language, sex, religious belief, political affiliation, social status or other considerations. True faith is the guarantee for enhancing such dignity along the path to human perfection..."

On the above article, though the basic dignity is not clearly defined, the second part gives light by clearly substantiating that "true faith is the guarantee for enhancing such dignity along the path to human perfection". ${ }^{17}$ This understanding is corroborated in the Quran:

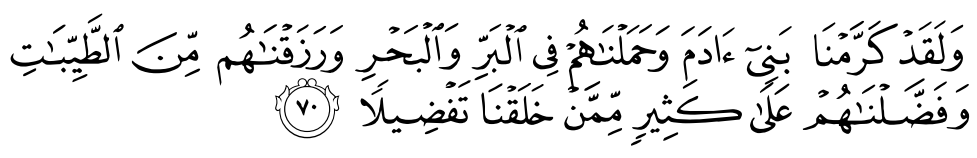

"We have indeed conferred dignity on the children of Adam..... and favoured them far above most of our creation..."

(Surah al-Isrā', 17: 70)

As stated in the above verse, the Quran has bestowed basic dignity to all humanity regardless of race, colour etc, and a comprehensive dignity can only be achieved through true devotion to the teaching of Islam and in specific piety (taqwa):

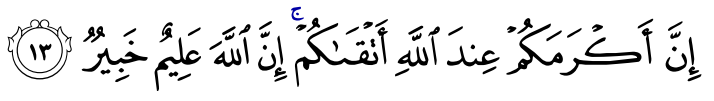

17 Kasule Omar, Contemporary Muslims and Human Rights Discourse: A Critical Assessment, 179. 
"Verily, the most honored of you in the sight of Allah is the most righteous..."

(Surah al-Ḥujurāt, 49: 13)

Article 1 (A) of the Cairo Declaration 1990, differs with the Universal Declaration on Human Rights 1948 regarding the rights and dignity. While the Universal Declaration asserts the equality, dignity, and rights in totality, the Cairo Declaration limits it to basic human dignity and basic rights, putting into consideration that Muslims, Polytheists, atheist and all Mushrikūn are not equal before Allah SWT. In section B of the Cairo Declaration further substantiates section A by stating that:

"All human beings are God's subjects and the most loved by Him are those who are most useful to the rest of His subjects and no one has superiority over another except on the basis of piety and good deeds..."

The Cairo Declaration, in other words, it asserts the verse in Quran which states:

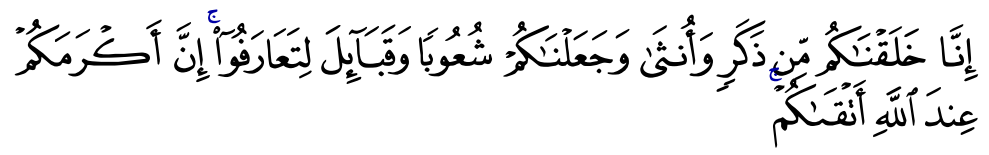

"And we have made you into tribes and nations so that you know each other, verily the most honored amongst you is the most heedful of you..."

(Surah al-Ḥujurāt, 49: 13)

Article 18 of Universal Declaration of human rights clearly states:

"Everyone has the right to freedom of thought, conscience and religion; this right includes freedom to change his religion or belief, and freedom, either alone or in Community with others and in public or private, to manifest his religion or belief in teaching, practice, worship and observance..." 18

This article of Universal Declaration explicitly supports apostasy (riddah) an area of serious concern in Islamic law. As much as Islam respects other faiths, and the Quran clearly stipulates: "There is no compulsion in religion" does not accept or condone apostasy, everyone has the choice and freedom to

18 United Nations High Commissioner for Human Rights, Universal Declaration of Human Rights. 
make a decision of becoming a Muslim, but one should be aware that changing the religion like political parties is not allowed in Islam. So an individual should know in advance, and if he feels he cannot fulfill the obligations then Shariah has not forced any individual to convert to Islam.

Article 19 of the Universal Declaration of Human Rights states:

"Everyone has the right to freedom of opinion and expression; this right includes freedom to hold opinions without interference and to seek, receive and impart information and ideas through any media and regardless of frontiers..." 19

This article advocates for freedom of opinion and expression without limit, through this perception, many people especially in the western world insults religions and even the prophets, as what happened to cartoons published by Denmark insulting our beloved prophet Muhammad SAW. In this article, religions are not spared or protected. While in contrary, the Cairo Declaration firmly states in Article 22, limits the freedom of opinion by reiterating that should not be contrary to the principles of Shariah:

"Everyone shall have the right to express his opinion freely in such manner as would not be contrary to the principles of Shariah..."

Article 16 of the Universal Declaration of Human Rights regarding the marriage states:

"Men and women of full age, without any limitation due to race, nationality or religion, have the right to marry and to found a family. They are entitled to equal rights as marriage, during marriage and at its dissolution..." 20

In this context, a Muslim woman can get married to any person of any religious affiliation and men likewise. This concept is against the basic tenets of Islam, it contradicts the Islamic family law, Muslim men are not allowed to marry non-Muslims unless they convert to Islam, while Muslim women are not allowed by Shariah to marry non-Muslim men, therefore, the Universal Declaration on Human Rights does not consider religion as a determining factor to marriage of any kind. While Article 5 of the Cairo Declaration affirms the Islamic position on marriage by considering religion as determining factor in

19 United Nations High Commissioner for Human Rights, Universal Declaration of Human Rights.

20 United Nations High Commissioner for Human Rights, Universal Declaration of Human Rights. 
marriage, although the Article has not specifically mentioned religion which is the most pertinent and great obstacle as Muslim women are not allowed to get married to non-Muslim men. Likewise, Muslim men are not allowed to marry Mushrikün unless they convert to Islam. This stands in not clearly elaborated in the Cairo Declaration, but still, do not accept the Universal declaration notion which does not consider religion in the marriage contract.

Article 5 of the Universal Declaration denounces torture, cruelty or degrading treatment. International western human rights bodies oppose Shariah especially hudūd by referring to this article as in their perception hudud is torture and cruelty. While Article 2 of the Cairo Declaration defends the Islamic position by stating: 2 (A)

"Life is a God-given gift and the right to life is guaranteed to every human being. It is the duty of individuals, societies and states to protect this right from any violation, and it is prohibited to take away life except for a Shariah prescribed reason."

Regarding the right to work, the Cairo Declaration of Human Rights does not contradict the Universal Declaration of Human Rights, thus affirming the right to work provided that it suits his interest and those of the society. This can imply that working in harām transactions are prohibited, thus it is confined in the interest of the society, referring to the Muslim society, who are definitely supposed to be governed by the Quran and Sunnah. On the other hand, the Universal Declaration of Human Rights is open with no restrictions. Article 23(1) states:

"Everyone has the right to work, to free choice of employment, to just and favorable conditions of work and to protection against employment..."

The declaration has mentioned the choice of employment without putting any restrictions, implying that, one can transact in any business regardless of it being considered haram like riba, alcohol, brothels etc.

Article 25 (2) of the Universal Declaration of Human Rights does not differentiate between children born in wedlock or out of wedlock as they will enjoy all the benefits of their parents equally. It means that they will inherit equally from their parents whether they were born in or out of wedlock. This contradicts the basic objectives of children born in wedlock is to safeguard their rights of inheritance, as if there is no marriage bond between the partners, there is high possibility of children enjoying inheritance not belonging to them, as such, one cannot certainly know the father of a child by the fact that the woman might have several relationships. This can be substantiated by the fact 
that, marriage is not considered and recognized as the only legitimate union in the Universal Declaration of Human Rights. Article 25 (2) of UDHR states:

"Motherhood and childhood are entitled to special care and assistance. All children, whether born in or out of wedlock shall enjoy the same social protection..."

Concerning equality, the Cairo Declaration on Human Rights in Islam affirms for equality of all the individuals before the law. This affirmation and confirmation have its own shortcomings and it's not realistic in the sense that, in an Islamic state, the non-Muslims are not bound by Shariah law, cannot be forced to follow Shariah in a bid to achieve equality. However, part (D) clarifies part (A) confining the Shariah to be implemented as provided by Shariah law.

Article 19(A) and (D) respectively of the Cairo Declaration on Human Rights in Islam states:

"All individuals are equal before the law, without distinction between the ruler and the ruled."

"There shall be no crime or punishment except as provided for in the Shariah."

On the other hand, the Universal Declaration on Human Rights asserting for absolute equality to all individuals while implementing its Declaration.

The following are some examples of human rights principles affirmed by the Quran and Sunnah which are also affirmed in Shariah as maqāșid alsharī'ah (Objectives of Shariah):

\section{Security of Life and Property}

During the Prophets Muhammad's farewell of hajj, he said: "your lives and properties are forbidden to one another till you meet your Lord on the Day of Judgment."

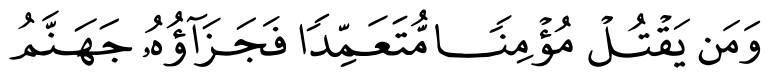

"Anyone who kills a believer deliberately will receive his reward as Hellfire..."

(Surah al-Nisā’, 4: 93)

In this regard, Islam affirms on the minority rights living in Muslim states. 


\section{Protection of Honor}

During the Prophets Muhammad's farewell of hajj, he not only prohibited the taking of other people's lives and properties but also any encroachment on their honour, respect, and chastity. This can be briefly explained in Surah alHujurāt (49: 11-12):

a) Oh you who believe, do not let a set of people make fun of another people.

b) Do not defame one another.

c) Do not insult by using nicknames.

d) And do not backbite and speak ill of one another.

\section{Sanctity and Security of Private Life}

\section{وَلَا بََستَستوُواْ}

"Do not spy one another..."

(Surah al-Ḥujurāt, 49: 12)

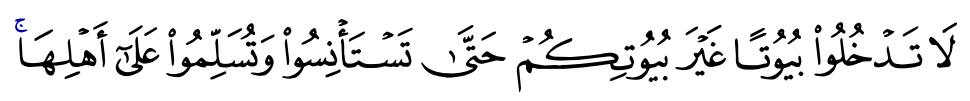

"Do not enter any houses except your own homes, unless you are sure of the occupant's consents..."

(Surah al-Nūr, 24: 27)

\section{Right to Justice}

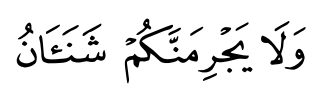

"Do not let your hatred incite you to aggression..."

(Surah al-Mā'idah, 5: 2)

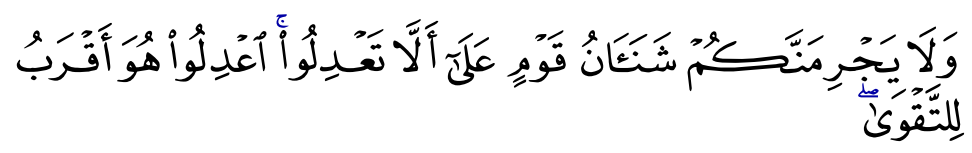

"And do not let ill-will towards any folk incite you so that you swerve from dealing justly. Be just that is nearest to taqwa..."

(Surah al-Mā'idah, 5: 8) 


\section{Equality of Human Beings}

All human beings are descendants of one father and one mother - Nabi Ādam and Hawā'.

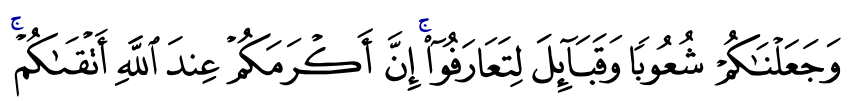

"And we have made you into tribes and nations so that you know each other, verily the most honored amongst you is the most heedful of you..."

(Surah al-Ḥujurāt, 49: 13)

Prophet Mohammad also insisting on this principle of equality. He narrated that in the meaning of hadìth as even when Fatimah bint Muhammad steals her hand will be amputated. To mean justice and equality in Islam are universal and not selective or discriminative.

\section{Respect and Protection of Other Religions}

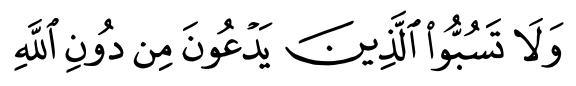

"Do not abuse those they appeal to instead of God..."

(Surah al-An‘ām, 6:108)

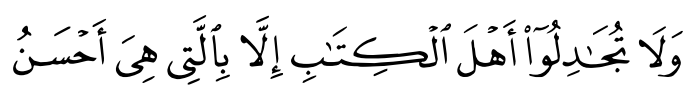

"Do not argue with the people of the book, unless it is in a politer manner..."

(Surah al-'Ankabūt, 29:46)

\section{HUMAN RIGHTS IN THE MUSLIM WORLD}

There are various debates surrounding Islam and Human Rights, in particular, challenging assumptions of a 'standard' or 'essential' Muslim perspective on Human Rights. A review of the experiences of Muslim communities across the globe shows the dynamic way Muslims understand and incorporate Human Rights into their personal, social and political experiences. 
It is often supposed that international human rights standards were negotiated without active participation by Middle Eastern and Muslim states. That was not the case. United Nations records document the contributions of Arab and Muslim diplomats from 1946-1966. Diplomats from the Islamic world did not always agree with each other, but their various contributions resulted in the assertion of a right to self-determination, the most comprehensive statement of universality, culturally sensitive language about religious beliefs, and a separate article promoting gender equality. Initially, they proposed robust mechanisms for implementation, and they actively opposed the isolation of socioeconomic rights into a separate covenant. Not all of their efforts were successful, and not all of their positions were liberal. While their role as participants and promoters of human rights should not be exaggerated, neither should it be discounted. ${ }^{21}$

In addition, in the last few years, issues related to human rights, including encouraging the democratization of Muslim societies from the Middle East to Southeast Asia, have acquired great importance in shaping the character of U.S.-Muslim relations and U.S. policy toward Muslim countries. An important impetus behind this development was the tragic events of $9 / 11$, which demonstrated the destructive potential of militant groups that use a distorted interpretation of Islam as justification for their actions. These events also led to a greater realization by the United States-and the West-that a lack of democracy and lack of respect for human rights have been contributory factors to the rise of 'militant of Islam'. Consequently, in its approach toward the Muslim world, the United States has emphasized the themes of human rights and democracy. Within the Islamic world, too, both secular and moderate Islamists have begun focusing on issues related to human rights. Although many conservative Muslims believe that Islam is incompatible with Western notions of democracy and human rights, reformist Muslim thinkers and activists maintain that a proper reading of Islamic injunctions and the ethical values underpinning those injunctions shows there is no such incompatibility. Complicating the debate is the fact that many Muslims-secular as well as conservative and reformist-doubt the seriousness of the U.S. commitment to the cause of human rights and democracy in the Muslim world, believing that the United States applies human rights' standards selectively to suit its strategic and economic interests. Irrespective of the validity of these charges,

21 Waltz, S. E., 'Universal Human Rights: The Contribution of Muslim States,' Human Rights Quarterly, 26/4 (2004): 799-844. 
they are part of the context of the U.S.-Muslim dialogue on human rights. It is this complex dialogue that this volume seeks to advance. ${ }^{22}$

To hundreds of millions of Muslims, the historical formulations of Islamic law known as Shari'a determine the boundaries of legal and ethical conduct. ${ }^{23}$ Islam may not be the sole factor for ensuring the realization of human rights in the Muslim States, it is certainly a significant factor that can be constructively employed as a vehicle for improving the poor human rights situation in the predominantly Muslim States that recognise Islam as State religion or apply Islamic law or Islamic principles as part of State law. ${ }^{24}$

\section{CONCLUSION}

The Universal Declaration on Human Rights (UNDR) 1948 and the Cairo Declaration on Human Rights (CDHR) 1990 in Islam have major differences which cannot be reconciled, therefore, Universal Declaration of Human Rights (UDHR) cannot be used and relied upon by Muslims. It has severe discrepancies and opposition to the Islamic law. It does not put into consideration religious values while preparing the Declaration. Can these rights really be considered as universal, while it has deliberately excluded section of humanity, especially the religious people while preparing these rights? Therefore we can firmly state that they are rights meant for specific people especially the western world and not the whole humanity. Any attempts by a section of Muslim to implement these rights collectively means that they will have to abandon the teachings of Islam at the expense of the secular western values, something which cannot be imagined leave alone implemented.

The following are our recommendations:

a) Muslim countries through Organization of Islamic Conference (OIC) should have effective human rights Charter to govern the Muslim countries to deter Western world interference in their internal affairs, under the guise of human rights protection and promotion.

22 Hunter, S. T., Malik, H., Mayer, A. E., Abou El Fadl, K., Hassan, R., Ibrahim, S. E., \& Pastor, R. A., 'Islam and Human Rights: Advancing a U.S.-Muslim Dialogue,' Religion and Human Rights (2005), 2.

23 An-Na'im, A. A., Human Rights in the Muslim World: Socio-Political Conditions and Scriptural Imperatives: A Preliminary Inquiry,' Harvard Human Rights Journal, 3 (1990): 13-52.

24 Baderin, M. A., 'Islam and the Realization of Human Rights in the Muslim World: A Reflection on Two Essential Approaches and Two Divergent Perspectives,' Muslim World Journal of Human Rights, 4/1 (2007): 1-25. 
b) Muslim leaders from all Muslim countries should stand by the Quran and Sunnah in order to portray the superiority of Islamic human rights over the western human rights perceptions.

c) Muslims are obliged by Shariah to protect and promote social justice affirmed by the Quran and Sunnah, This can be achieved by implementing the concept of maqāssid al-sharī'ah (Objectives of Shariah), in doing so, Muslims will not need any instruments of western human rights to remedy the devastating situation of Muslims.

\section{REFERENCES}

Abd Alrahim, Muddathir, The Human Rights Tradition in Islam, 1st ed. (America: Praeger Publishers, 2005).

Abu A'ala Maududi, Human Rights in Islam (London, Nairobi, Kano: Islamic Foundation, 1983).

An-Na'im, A. A., Human Rights in the Muslim World: Socio-Political Conditions and Scriptural Imperatives: A Preliminary Inquiry,' Harvard Human Rights Journal, 3 (1990): 13-52.

Anonymous, 'Cairo Declaration on Human Rights in Islam: Adopted and Issued at the Nineteenth Islamic Conference of Foreign Ministers in Cairo on 5 August 1990,' Forced Migration Review, 8 (2012), 1-5.

Hunter, S. T., Malik, H., Mayer, A. E., Abou El Fadl, K., Hassan, R., Ibrahim, S. E., \& Pastor, R. A., 'Islam and Human Rights: Advancing a U.S.Muslim Dialogue,' Religion and Human Rights (2005), 1-144.

Jack Donnelley, International Human Rights, $2^{\text {nd }}$ ed. (Colorado and Oxford: West View Press, 1998).

Jah Omar, 'Human Rights in Islam: Judicial Rights, Sanction and Penalties,' Al-Shajarah, 7/1 (2002): 89-105.

Kasule Omar, Contemporary Muslims and Human Rights Discourse: A Critical Assessment (Malaysia: IIUM Press, 2009).

Lawson Edward (ed.), Encyclopedia of Human Rights (New York, Philadelphia, Washington and London: Taylor and Francis Inc., 1991).

Mashood Baderin, 'Islam and the Realization of Human Rights in the Muslim World: A Reflection on Two Essential Approaches and Two Divergent Perspectives,' Muslim World Journal of Human Rights, 4/1 (2007): 1-25.

Organization of Islamic Conference, Cairo Declaration on Human Rights in Islam (Jeddah: Organisation of Islamic Conference, 1990). 

and the Cairo Declaration on Human Rights

United Nation General Assembly, 'Universal Declaration of Human Rights,' The International Journal of Human Rights, 2/3 (1998): 84-88.

Waltz, S. E., 'Universal Human Rights: The Contribution of Muslim States,' Human Rights Quarterly, 26/4 (2004): 799-844. 
Jurnal Syariah, Jil. 26, Bil. 1 (2018) 123-140 